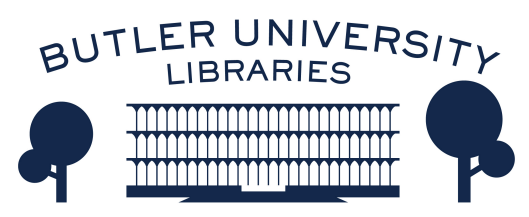

Journal of Hindu-Christian Studies

Volume 4

Article 7

January 1991

\title{
Viewpoints: Art and Architecture as Locus for Dialogue: Inter- Religious Dialogue Through Art
}

\author{
Caroline MacKenzie
}

Follow this and additional works at: https://digitalcommons.butler.edu/jhcs

Part of the Religion Commons

\section{Recommended Citation}

MacKenzie, Caroline (1991) "Viewpoints: Art and Architecture as Locus for Dialogue: Inter-Religious Dialogue Through Art," Journal of Hindu-Christian Studies: Vol. 4, Article 7.

Available at: https://doi.org/10.7825/2164-6279.1045

The Journal of Hindu-Christian Studies is a publication of the Society for Hindu-Christian Studies. The digital version is made available by Digital Commons @ Butler University. For questions about the Journal or the Society, please contact cbauman@butler.edu. For more information about Digital Commons @ Butler University, please contact digitalscholarship@butler.edu. 


\title{
VIEWPOINTS
}

\section{Art and Architecture as Locus}

\section{for Dialogue}

\section{Inter-Religious Dialogue Through Art}

\author{
Caroline MacKenzie \\ 5, Danyrallt, Llaneglwys, Builth Wells, LD2 3BJ, UK
}

THE EPIC RĀMĀYAṆA is a central Hindu Scripture, which, unlike the Vedas and Upanișads, has been accessible to all sections of the Society. The story originated from an oral tradition and was written down by the sage Vâlmīki. The date is disputed and could be anything between 1500 and $200 \mathrm{BC}^{1}$ It is said to be the "ádikavya", the first and the ideal poem.

My encounter with the Rămãyana took place when I was young, brought up in the West as a token Christian. When I went to India after completing a degree at St. Martin's School of Art, London, I was searching for an identity. To discover this, I felt that I needed a model, a type of hero with whom I could in some way identify myself. Somehow the historical Jesus I had been brought up with did not appeal to me. I could not see the connection between my experience as a twentieth century woman and the Jesus presented either as Jew who lived two thousand years ago or as a North European Renaissance man. On the other hand, the hero and the heroine of the Rãmãyana, Rãma and Sĩtã spoke to my humanity. The Rămãyaña is a Scripture and through this humanity the reader is led to a theophany. At the end of the story Rama and Sītã are revealed as God and Goddess incarnate. The Rămãyana is presented in the form of a myth. It has a timeless, archetypal quality that makes it applicable to each particular gen- eration in a new way. There are literally hundreds of versions of the Rảmãyana, each one giving a slightly different shift in emphasis, yet retaining the core message of the story.

According to the Indian aesthetic theory of "dhvani", when a person interprets a text, what he or she sees to be its significance may be influenced by his or her background. Writers on dhvani take the phrase, "the sun has set", to illustrate this. This phrase may evoke differently to different people according to circumstances: to a lover it may mean, 'it is time for a rendezvous', for a soldier, 'it is time to attack the enemy', to a religious person, 'it is time to begin the evening worship' and so on. ${ }^{2}$ In this approach there is not so much a right or wrong interpretation but rather richer meanings that enlarge the horizon for us. When I embarked on making a series of wood-cut prints inspired by the Rãmãyana, I was unconsciously following this method. (I read about it only after completing the work). Basically I was approaching the text with the experiences and questions of a twentieth century woman. I wanted to have my own career and not to find my meaning solely in relation to a man as wife and mother.

One of my central questions was "Am I made in the image of God?" My childhood experience of images of the Jesus depicted either as a Jew or as a European man, led me to feel at a gut level (as opposed to intellectually) that 
I was irredeemably inferior to men. Social pressures suggested that the only hope of redemption was for a woman to attach herself to a man. This might have been a viable possibility if such a relationship allowed both the man and the woman to develop their full potentials. However what I observed as the norm was that men liked women to assist them in their creativity. This attitude seemed to be reinforced by the Adam and Eve story where Eve is born out of Adam's rib in order to be his helpmate.

Another question I had was about the earth. The most pressing problem in the world seemed to be the progressive exploitation of the earth by our industrial civilisation. The historical Jesus was concerned for the poor and the blind human beings but the poor and suffering earth seemed to be beyond his interest. Any intercessory prayers that I heard in Church concerned justice for people. I was led to conclude that the justification for the ruthless exploitation of the earth was in order to liberate human beings.

These were some of the questions in my mind when approaching the Ramáyana. For an artist emotions and imagination play as important a part as ideas. There is an Indian story about a King who wanted to make a sculpture. He asked a sage how to go about this. The sage told him he should first learn painting. How should I do this? the king asks. For that you need to learn dancing. To learn dancing you should learn music. And so the story goes on. The point that is made here is that all the arts are interconnected. My entry into the Ramãyana was through drama although the final work was pictures.

Soon after arriving in India and reading the Rămãyana, I attended a drama workshop. Each participant had to mime a character and the others to guess who it was. I acted out a part of the Rămanyana which had particularly struck me. It was the despair of the heroine Sìtã who is captured by a demon King Ravana, on the island of Lankā. Rãvana says he will force her to become his wife if she will not freely submit to him. Sitã has been resisting by saying that her husband Răma will come to rescue her. But the days have passed and still he has not come. Rãvaña views Sĩtă in an entirely materialistic way; she is a beautiful object to be possessed. On the other hand, according to my understanding of the text, Răma views her as a creative individual. His love for her is empowered while Rāvanan's is imprisoning. This situation mirrored my despair with my own situation. At a very deep level I felt imprisoned by the feeling that I was merely a material body without a divine centre. All the symbols around me were like the prison made by Rãvana. This despair was articulated in the paintings of the contemporary British artist Francis Bacon. ${ }^{3} \mathrm{He}$ is only interested in despair. But the Rămāyana story is not content with despair alone, although it explores such feelings in depth.

When Sîta has reached a point where she decides it will be better to hang herself than to submit to Răvana, Hanuman, the messenger from Rāma, appears. He is depicted as a monkey. He speaks to Sìtå of Răma and his love for her. Then he gives her Răma's ring which he has sent as a token. Sìtã is overjoyed. There is a complete change in her emotional state. This change from despair, and transformation into hope through the meeting with Hanuman gave dramatic scope. Hanuman in some way represented the hopeful worldview I encountered in Indian culture and symbolism.

After making this dramatic identification with Sìtá, I began to work on a set of woodcut prints based on the Rămanyana. At the time I was doing this, I was staying at INSCAPE (Indian School of Art for Peace). The director Jyoti Sahi, one of the foremost Indian Christian artists, was often commissioned to do sets of Stations of the Cross. These were very original and incorporated Indian symbolism. The figure of Christ often looked a bit like the artist himself. This was not done consciously. I liked the Indian symbolism, but because of past problems with the historical Jesus pictures of my background, I felt excluded from the transformative journey made by Christ in these stations because he was a man.

I decided that I could make a set of Stations of the Rămayana. This gave me scope for the same type of themes as in the normal fourteen Stations of the Cross, i.e. there are despair scenes which are equivalent to the "Falls" in the Stations, and there are helping scenes which relate to the events like Christ being 
helped by Simon of Cyrene, and Veronica wiping his face. The great advantage for me in the Rămayana was that these events were divided between Răma and Sitã. So I could see a man in despair and a woman in despair. Both of them "get up" from their "falls", without any bitterness towards their situations, which I in the same predicament would have felt. The story also includes helping animals, such as deer and monkeys and is set in the primal landscape of the forest. Thus the earth and the whole vegetable world is clearly included.

When the set was finalised I had an exhibition of the paintings. Some of the Hindus who saw the pictures felt I had depicted the Rămãyaṇa in a new way. They felt my interpretation of Sìtã made her out to be much stronger than the traditional one. The most controversial image was of Sìtâ in the fire. Especially Indian feminists see the rejection of Sītã by Råma, which results in her entering the fire as a typical patriarchal atrocity. I saw this image of Sita in the fire as thoroughly positive. This was because it threw important light on my question as to whether woman is made in the image of God.

It is when Sĩtã is in the fire that a heavenly voice declares that Sìtã is in fact an incarnation of the Goddess Lakșmi, while Răma is Lord Narayana. This revelation of the divinity in the context of a freely chosen death (Sìtã chooses to enter the fire) resonated for me with the whole mystery of the crucifixion. The spirit of the fire testifies to Sìta's integrity and she emerges from the fire unscathed. As with the Cross of Jesus, which has helped people to focus on God's involvement with the suffering of humanity, particularly the poor and the oppressed, the image of Sita in the fire focuses attention on the suffering of women and of the earth. Sītã was born out of the earth, and like all women (at one level) she symbolises the earth. The power of Christ crucified is that he overcomes death, and thus he gives hope. In the same way Sĩta emerges from the fire unscathed. Sītã was rejected because Rãma could not trust her since she had been in the kingdom of Rãvana. One of the reasons that Nature has been desacralised is because it has been seen as untrustworthy. Sitã's survival through the fire is a theophany showing that she is made in the image of God and she is to be trusted.

Inter-religious dialogue through art, could perhaps be termed inter-religious dialogue through heart. When I got involved with the Ramãyaña, I had no intention of dialoguing with Hinduism. Since I was not a Christian at that time, this would have been impossible. It was in doing this work that I discovered Christ in a convincing way. It was the Rămăyana that enabled me to move away from the historical Jesus towards "the quest for the Cosmic Christ". ${ }^{4}$ The cosmic Christ, Mathew Fox writes, is the pattern that connects. Because of my background the pattern that really connected me to the Rãmãyaṇa was the Christian one.

The rich poetic scriptural content of the Rămãyana has given rise to literally hundreds of versions of it. There is the famous one in Hindi by Tulsidas and the Kamba Rămãyana in Tamil. There is a Jain Ramãyana and so on. Perhaps without intending to, I made a Christian Rămãyana. By doing this the Christian symbols were enriched so as to convince me that women are made in the image of God, and that the suffering and pain of the earth is within the scope of God's concern. Perhaps the Hindu symbols were also enriched, but that would be for a Hindu to say.

A set of the pictures described above is owned by Ashirvad, Bangalore, S. India. These are oil on canvas. Original hand printed woodcut prints of the series are available singly or the whole set bound, from C. Mackenzie, Sandeepani, 5, Danyrallt, Llaneglwys, Builth Wells, LD2 3BJ UK. The pictures and prints have been exhibited in India already:

1983 Max Müller Bhavan, Bangalore - Woodcut prints.

1985 Alliance Française, Bangalore-Oil Paintings.

1988 British Council, Madras-Sìtã as a Woman Artist. Woodcut-prints and paintings. All the exhibitions were reviewed in the press. 
Viewpoints 34

\section{Footnotes}

1 The Rāmāyana of Vālmikki. Condensed and translated by P. Lal. N. Delhi, Vikas, 1981. p. xxii.

2 Anand Amaladass. Philosophical Implications of Dhvani, Vienna, De Nobili Research Library, 1984. p. 192.
3 John Russell. Francis Bacon. London, Thames and Hudson, 1971.

4 Mathew Fox. The Coming of the Cosmic Christ, San Francisco, Harper and Row, 1988. p. 7. 